\title{
Sensitivity and specificity of infrared thermography in detection of subclinical mastitis in dairy cows
}

\author{
B. Polat, ${ }^{*}$ A. Colak, ${ }^{*}$ M. Cengiz,† L. E. Yanmaz,‡ H. Oral,§ A. Bastan,† S. Kaya,§ and A. Hayirli\# ${ }^{1}$ \\ *Department of Obstetrics and Gynecology, Faculty of Veterinary Medicine, Atatürk University, Erzurum 25240, Turkey \\ †Department of Obstetrics and Gynecology, Faculty of Veterinary Medicine, University of Ankara, Ankara 06110, Turkey \\ ‡Department of Surgery, Faculty of Veterinary Medicine, Atatürk University, Erzurum 25240, Turkey \\ $\S$ Department of Obstetrics and Gynecology, Faculty of Veterinary Medicine, Kafkas University, Kars 36100, Turkey \\ \#Department of Animal Nutrition and Nutritional Disorders, Faculty of Veterinary Medicine, Atatürk University, Erzurum 25240, Turkey
}

\section{ABSTRACT}

The objectives of this experiment were to determine interrelationships among mastitis indicators and evaluate the subclinical mastitis detection ability of infrared thermography (IRT) in comparison with the California Mastitis Test (CMT). Somatic cell count (SCC), CMT, and udder skin surface temperature (USST) data were compiled from 62 Brown Swiss dairy cows (days in milk $=117 \pm 51$, milk yield $=14.7 \pm 5.2 \mathrm{~kg}$; mean $\pm \mathrm{SD}$ ). The CORR, REG, and NLIN procedures of Statistical Analysis System (SAS Institute Inc., Cary, NC) were employed to attain interrelationships among mastitis indicators. The diagnostic merit of IRT as an indirect measure of subclinical mastitis was compared with CMT using the receiver operating characteristics curves. The udder skin surface temperature was positively correlated with the CMT score $(\mathrm{r}=0.86)$ and $\mathrm{SCC}(\mathrm{r}=$ 0.73). There was an exponential increase in SCC (SCC, $\times 10^{3}$ cells $\left./ \mathrm{mL}=22.35 \times \mathrm{e}^{1.31 \times \text { CMT score }} ; \mathrm{R}^{2}=0.98\right)$ and a linear increase in USST (USST, ${ }^{\circ} \mathrm{C}=33.45+1.08 \times$ CMT score; $\left.\mathrm{R}^{2}=0.75\right)$ as the CMT score increased. As SCC increased, USST increased logarithmically [USST, ${ }^{\circ} \mathrm{C}=28.72+0.49 \times \ln \left(\mathrm{SCC}, \times 10^{3}\right.$ cells $\left./ \mathrm{mL}\right) ; \mathrm{R}^{2}=$ 0.72]. The USST for healthy quarters (SCC $\leq 400,000$ cells $/ \mathrm{mL} ; \mathrm{n}=94$ ) was different from that for subclinical mastitic quarters $(\mathrm{SCC}>400,000$ cells $/ \mathrm{mL} ; \mathrm{n}=135)$ $\left(\right.$ mean $\pm \mathrm{SE} ; 33.45 \pm 0.09$ vs. $\left.35.80 \pm 0.08^{\circ} \mathrm{C}\right)$. The sensitivity, specificity, positive likelihood ratio, negative likelihood ratio, positive predictive value, and negative predictive value were $95.6,93.6,14.97,0.05,95.0$, and 93.6, respectively, for IRT and 88.9, 98.9, 83.56, 0.11, 99.2, and 86.1, respectively, for CMT. The area under the receiver operating characteristics curve for IRT and CMT was not different. In conclusion, as a noninvasive and quick tool, IRT can be employed for screening subclinical mastitis via measuring USST, with a

Received October 8, 2009

Accepted April 2, 2010.

${ }^{1}$ Corresponding author: ahayirli_2000@yahoo.com high predictive diagnostic ability similar to CMT when microbiological culturing is unavailable. However, the reliability of IRT among cows with different characteristics and those living under various environmental conditions remains to be determined.

Key words: infrared thermography, udder skin surface temperature, California Mastitis Test, somatic cell count

\section{INTRODUCTION}

Mastitis occurs worldwide with a high prevalence and is associated with suppressed milk production; discharged milk; deteriorated milk quality; increased veterinary, drug, and labor costs; shortened longevity; and increased culling rate (Sargeant et al., 1998). Moreover, it interferes with energy balance and immune potency and consequently leads cows to be prone to metabolic disorders (Rajala-Schultz and Grohn, 1999). In surveys performed in Brazil (Holanda et al., 2005) and the United States (Erskine et al., 2003), it was reported that the total annual costs because of mastitis were $\$ 126 /$ cow and $\$ 45 /$ lactation. Similar figures from many countries are also available in the literature, suggesting that effective mastitis control programs covering its early diagnosis are more prominent than its treatment.

Numerous biomarkers and tests have been proposed to detect subclinical mastitis (Viguier et al., 2009). These biomarkers broadly include SCC; milk enzymes such as alkaline phosphatase, aspartate aminotransaminase, $N$-acetyl- $\beta$-D-glucosaminidase, and L-lactate dehydrogenase; milk components such as lactose, protein, fat, minerals $(\mathrm{Cl}, \mathrm{Ca}$, and $\mathrm{Na})$, and lactate; milk $\mathrm{pH}$ and temperature; acute phase proteins such as milk haptoglobulin and serum amyloid A and C-reactive protein; and others such as plasma $\beta$-carotene and ceruloplasmin. The tests to detect subclinical mastitis include electrical conductivity, California Mastitis Test (CMT), Wisconsin Mastitis Test, and Whiteside Test. These tests may not be suitable for field practice because they are subjective and have highly variable pre- 
dictive ability (Jensen and Knudsen, 1991; Woolford et al., 1998; Bansal et al., 2005; Chagunda et al., 2006).

Infrared thermography (IRT) is a sophisticated technology originally developed for military and industrial purposes (Mazur and Eugeniusz-Herbut, 2006). It is based on the principle that all objects emit infrared radiation proportional to their temperature according to the Stefan-Boltzmann law via conduction, convection, and radiation. A thermal camera absorbs infrared radiation and generates pictorial images based on the amount of heat generated, without causing radiation exposure (Eddy et al., 2001; Mazur and EugeniuszHerbut, 2006; Kunc et al., 2007). In general, on a thermograph, the warmest areas appear white or red whereas the coolest regions appear blue or black (Eddy et al., 2001; Colak et al., 2008).

In several studies, IRT has been employed to detect infectious diseases and monitor welfare status in farm animals (Clark and Cena, 1977; Menesatti et al., 2004; Stewart et al., 2005, 2007; Knížková et al., 2007). Despite lacking specificity for etiology, it provides useful information about presence of pathology (Eddy et al., 2001), especially for mastitis (Schaefer et al., 2004). Udder temperature is closely correlated with body temperature in nonmastitic cows (Bitman et al., 1984; Kennedy et al., 2003). Infrared thermography is shown to be sensitive enough to detect changes in udder skin surface temperature (USST) caused by milking, environmental temperature, and exercise (Berry et al., 2003; Kennedy et al., 2003). Udder skin surface temperature changes upon lipopolysaccharide administration (Willard et al., 2007), suggesting a possibility of early detection of subclinical mastitis using IRT (Barth, 2000; Schaefer et al., 2000; Colak et al., 2008), which is crucial to treating mastitis early and efficiently. This experiment was conducted to determine interrelationship among mastitis indicators including CMT, SCC, and USST and to examine the ability of IRT to detect subclinical mastitis defined by SCC at 2 cut-offs (above or below both 400,000 cells/mL and 200,000 cells/mL) in comparison with CMT.

\section{MATERIALS AND METHODS}

\section{Cows, Management, and Measurements}

Sixty-two lactating Brown Swiss dairy cows (DIM = $117 \pm 51$; milk yield $=14.7 \pm 5.2 \mathrm{~kg}$, mean $\pm \mathrm{SD}$ ) from a private farm with a portable milking system were screened for subclinical mastitis. In a free stall barn with straw bedding, cows were milked twice daily and were on a poor feeding program (free choice of wheat straw and haylage plus $1 \mathrm{~kg}$ of concentrate/head during each milking).
Written consent from the farmer and official approval from the Atatürk University Ethic Committee on Experimental Animal Use were obtained before the experiment. Rectal temperature and heart and respiration rates were measured $1 \mathrm{~d}$ before screening cows for subclinical mastitis. Cows were also subjected to visual examination, rectal and udder palpations (to check swelling, tissue texture, hypersensitivity, and redness), and milk test (to check clot, homogeneity, and color) to identify systemic infections such as digestive and pulmonary diseases, uterine infections, and clinical mastitis. To avoid ambiguous USST data, cows with problems other than subclinical mastitis were treated and excluded from the study.

To minimize interferences of light, humidity, and air flow and to adapt the cows to the same conditions, cows were moved to a room not receiving sunshine with a temperature of 18 to $23^{\circ} \mathrm{C}$ before milking. After allowing cows to rest for $30 \mathrm{~min}$ in this room, USST was measured by IRT (IR FlexCam S, Infrared Solutions Inc., Plymouth, MN) as described by Berry et al. (2003). Briefly, before each measurement, thermograph resolution was calibrated to room temperature. While the cow was in a standing position, her tail was held away and thermograph scans were directed toward each quarter, lateral to front quarters and caudal to rear quarters between legs, from a distance of $0.5 \mathrm{~m}$.

After USST measurements, foremilk milk (about 10 $\mathrm{mL}$ ) was discarded before CMT (Schalm and Noorlender, 1957) and then milk was sampled for SCC (Bentley IBC-M, Bentley Instruments Inc., Chaska, $\mathrm{MN})$. The USST measurement and sample collection for SCC were performed at a.m. and p.m. milkings, whereas CMT was performed only at a.m. milking. The quarters with SCC $\leq 400,000$ cells $/ \mathrm{mL}$ were considered healthy and those with SCC $>400,000$ cells $/ \mathrm{mL}$ were considered subclinical mastitic (Sears and McCarthy, 2003). Because of variation in defining subclinical mastitis based on SCC cut-off (De Vliegher et al., 2001; Chagunda et al., 2006), evaluations (healthy vs. subclinical mastitic) were also made based on considering 200,000 cells/mL as cut-off.

\section{Statistics}

The SCC and USST data obtained at a.m. and p.m. milkings were averaged before statistical analyses and then subjected to the PROC UNIVARIATE to assess linearity (SAS, 1999). The PROC MEANS was computed to obtain their descriptive statistics by the CMT score. Differences in mastitis indicators by the quarter location and CMT score were determined using PROC MIXED with the PDIFF option. Interrelationships among mastitis indicators were attained using 
Table 1. Descriptive statistics of the SCC $\left(\times 10^{3}\right.$ cells $\left./ \mathrm{mL}\right)$ and udder skin surface temperature (USST, $\left.{ }^{\circ} \mathrm{C}\right)$ of quarters by the California Mastitis Test (CMT) score $^{1}$

\begin{tabular}{|c|c|c|c|c|c|c|c|c|}
\hline \multirow{2}{*}{ Descriptive measure } & \multicolumn{8}{|c|}{ CMT score $^{2}$} \\
\hline & \multicolumn{2}{|c|}{ Negative $(\mathrm{n}=75)$} & \multicolumn{2}{|c|}{$+1(\mathrm{n}=33)$} & \multicolumn{2}{|c|}{$+2(\mathrm{n}=84)$} & \multicolumn{2}{|c|}{$+3(\mathrm{n}=37)$} \\
\hline Mean & 65 & 33.23 & 430 & 34.64 & 1,236 & 35.73 & 3,653 & 36.27 \\
\hline Median & 21.5 & 33.30 & 340.5 & 34.60 & 1,069 & 35.80 & $3,948.5$ & 36.20 \\
\hline Mode & 1 & 33.10 & 274 & 34.30 & - & 35.60 & - & 36.80 \\
\hline Minimum & 1 & 31.50 & 235 & 33.10 & 400 & 34.20 & 2,119 & 35.40 \\
\hline Maximum & 227 & 34.70 & 1,035 & 35.80 & 2,623 & 37.90 & 5,102 & 37.10 \\
\hline Kurtosis & 0.77 & -0.29 & 1.80 & -0.64 & -0.84 & 1.83 & -1.09 & -0.97 \\
\hline Skewness & -0.99 & -0.64 & 1.33 & -0.28 & 0.50 & 0.21 & -0.28 & -0.14 \\
\hline
\end{tabular}

${ }^{1}$ Linearity test, $P<0.0001$.

${ }^{2} \mathrm{n}=$ the number of quarters.

PROC CORR, REG, and NLIN. The receiver operating characteristics (ROC) curves for IRT and CMT were established to compare their sensitivity (ability to detect subclinical mastitis), specificity (ability to avoid misclassifying healthy quarters as subclinical mastitic), positive likelihood ratio (low specificity or how much the odds of the disease increase when a test is positive), negative likelihood ratio (low sensitivity or how much the odds of the disease decrease when a test is negative), positive predictive value (the probability that a subclinical mastitic cow with a positive test result really does have the condition for which the test was conducted), and negative predictive value (the probability that a subclinical mastitic cow with a negative test result really is free of the condition for which the test was conducted) for detecting subclinical mastitis as attained by SCC (MedCalc version 9.6.2.0, MedCalc Software, Mariakerke, Belgium). Statistical significance was declared at $P<0.05$.

\section{RESULTS}

\section{Interrelationships Among Mastitis Indicators}

There were no differences in mastitis indicators among the left front $(\mathrm{n}=59)$, left rear $(\mathrm{n}=55)$, right front $(\mathrm{n}=58)$, and right rear $(\mathrm{n}=57)$ quarters; the mean values $( \pm \mathrm{SE})$ were $12.53 \pm 0.36$ for $\ln (\mathrm{SCC})(P$ $<0.39)$ and $34.82 \pm 0.19$ for USST $(P<0.52)$ and the median CMT score was +2 . The mean $\mathrm{SCC}$ values $(x$ $10^{3}$ cells $/ \mathrm{mL}$ ) were $65,430,1,236$, and 3,650 and the mean USST values $\left({ }^{\circ} \mathrm{C}\right)$ were $33.23,34.64,35.73$, and 36.27 for quarters with the CMT score of negative (n $=75),+1(\mathrm{n}=33),+2(\mathrm{n}=84)$, and $+3(\mathrm{n}=37)$, respectively. The descriptive statistics of mastitis indicators by the CMT score are presented in Table 1 .
All mastitis indicators were interrelated. The USST was positively correlated with SCC $(\mathrm{r}=0.73)$ and the CMT score $(\mathrm{r}=0.86 ; P<0.0001)$. There was an exponential increase in SCC as the CMT score increased $\left(\mathrm{SCC}, \times 10^{3}\right.$ cells $/ \mathrm{mL}=22.35 \times \mathrm{e}^{1.31 \times \text { CMT score }} ; \mathrm{R}^{2}=$ $0.98 ; P<0.0001)$. This relationship was, expectedly, linear after natural log-transformation of SCC $[\ln (\mathrm{SCC})$ $=1.31 \times$ CMT score $\left.+10.02 ; \mathrm{R}^{2}=0.98 ; P<0.0001\right]$. As the CMT score increased, USST linearly increased $\left(\mathrm{USST},{ }^{\circ} \mathrm{C}=33.45+1.08 \times \mathrm{CMT}\right.$ score; $\mathrm{R}^{2}=0.75$; $P<0.0001$ ). The relationship between USST and SCC was fitted best to a logarithmic equation [USST, ${ }^{\circ} \mathrm{C}=$ $32.12+0.49 \times \ln \left(\mathrm{SCC}, \times 10^{3}\right.$ cells $\left./ \mathrm{mL}\right) ; \mathrm{R}^{2}=0.73 ; P$ $<0.0001$; Figure 1].

\section{Feasibility of Infrared Thermography in Detection of Subclinical Mastitis}

The USST (mean $\pm \mathrm{SE}$ ) was $33.45 \pm 0.09$ and 35.80 $\pm 0.08^{\circ} \mathrm{C}$ for healthy $(\mathrm{SCC} \leq 400,000$ cells $/ \mathrm{mL} ; \mathrm{n}=94)$ and subclinical mastitic $(\mathrm{SCC}>400,000$ cells $/ \mathrm{mL} ; \mathrm{n}=$ $135)$ quarters $(P<0.0001)$. The sensitivity, specificity, positive likelihood ratio, negative likelihood ratio, positive predictive value, and negative predictive value were, respectively, 95.6, 93.6, 14.97, 0.05, 95.0 and 93.6 for IRT and $88.9,98.9,83.56,0.11,99.2$, and 86.1 for CMT when subclinical mastitis was defined according to $\mathrm{SCC}$ ( $\mathrm{SCC} \leq 400,000$ cells $/ \mathrm{mL}$ being healthy vs. SCC $>400,000$ cells/mL being subclinical mastitic; Table 2). The area under the ROC curve for USST (0.985) and CMT (0.983) was not different ( $z$-value of $0.19 ; P<$ 0.85 ; Figure 2).

The predictive ability of IRT depending on various SCC categorizations is summarized in Table 2. In general, cut-off values of USST increased as SCC increased. When quarters were categorized as healthy 


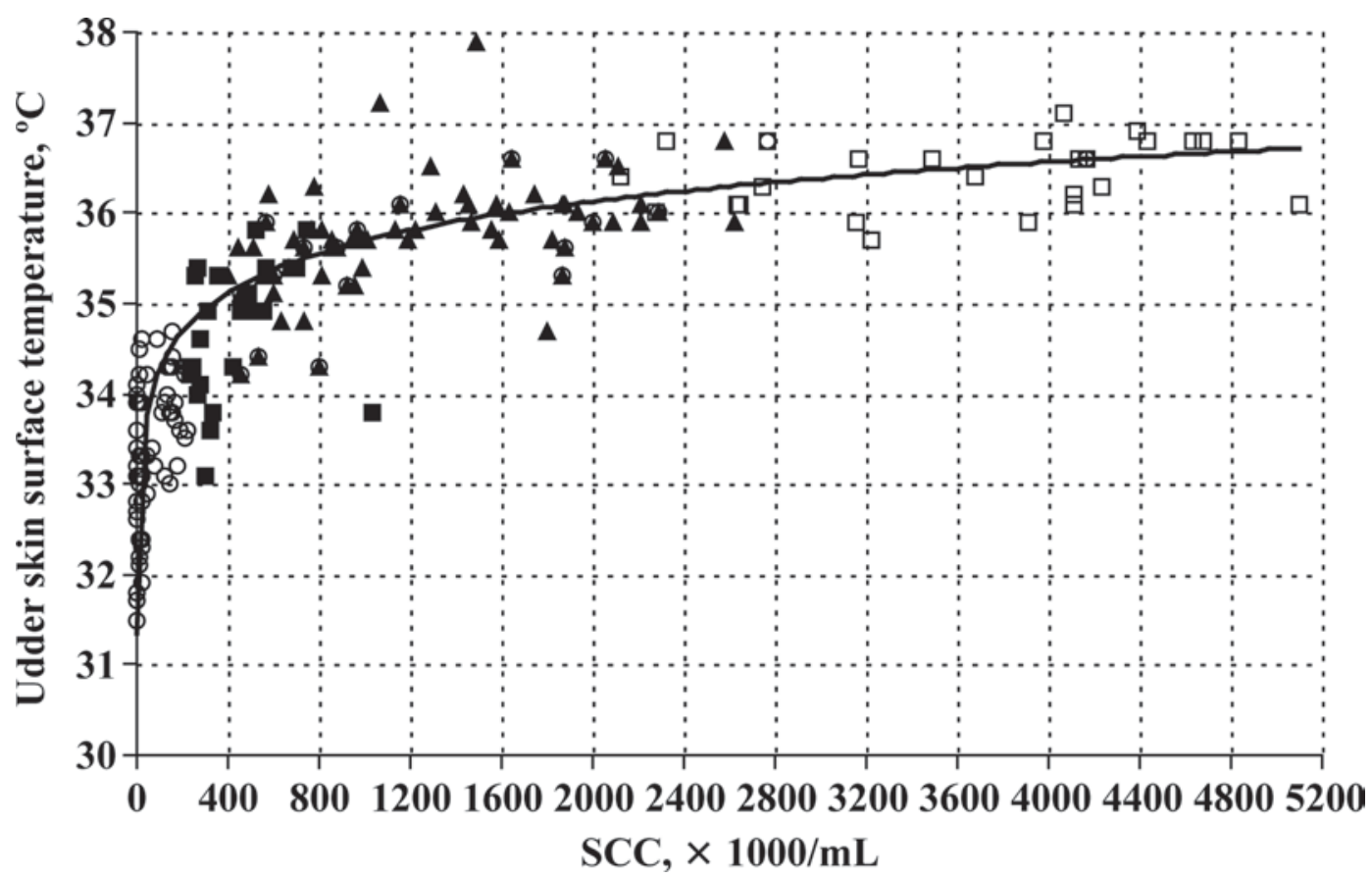

Figure 1. Relationship between SCC and the udder skin surface temperature (USST) of quarters determined by infrared thermography $\left[\mathrm{USST},{ }^{\circ} \mathrm{C}=32.12+0.49 \times \ln \left(\mathrm{SCC}, \times 10^{3}\right.\right.$ cells $\left.\left./ \mathrm{mL}\right), \mathrm{R}^{2}=0.73, P<0.0001\right] .0:$ California Mastitis Test $(\mathrm{CMT})$ score $=$ negative, $\mathrm{n}=75$ CMT score $=+1, \mathrm{n}=33 ; \boldsymbol{\Delta}:$ CMT score $=+2, \mathrm{n}=84 ; \square:$ CMT score $=+3, \mathrm{n}=37$.

$(\mathrm{SCC} \leq 200,000$ cells $/ \mathrm{mL})$ versus subclinical mastitic (SCC $>200,000$ cells $/ \mathrm{mL}$ ), the sensitivity, specificity, positive likelihood ratio, negative likelihood ratio, positive predictive value, and negative predictive value of IRT were 83.47 (75.6-89.6), 100 (93.6-100), not determined, 0.17 (not determined), 100 (96.4-100), and 73.7 (62.2-83.2), respectively, at cut-off of $34.7^{\circ} \mathrm{C}$ (values in parentheses are 95\% CI; Figure 3).

\section{DISCUSSION}

Early detection of mastitis is important for effective and successful treatment to reduce economical and biological losses associated with mastitis (Sargeant et al., 1998). Numerous biomarkers and tests-at-farm for detecting subclinical mastitis are available. However, none of them is perfect and fully accurate. In this study, IRT was proposed as a rapid and noninvasive technique for early detection of subclinical mastitis. Three biosystems participate in the development of mastitis: the host (i.e., breed, parity, and production level), cause (i.e., pathogen, chemical, and trauma), and environment (i.e., season and management) and their interactions. Certain number of cells is tissue origin known as glandular cells, protective cells, or polymorph nuclear leukocytes. Leukocytes in milk upon microbial penetration are directly related to the degree of inflammation (Viguier et al., 2009). Clinical mastitis is recognized by abnormal milk (SCC over 500,000 cells/mL and rheological deterioration) and gland swelling and hypersensitivity (McDougall, 1999). Subclinical mastitis, however, is characterized by apparently normal milk, with an increase in SCC (up to 400,000 cells/mL) because of the influx of leukocytes (Sears and McCarthy, 2003). Somatic cell count is considered the best indicator of inflammatory response because it is associated with milk yield loss and alteration in milk properties, starting from 50,000 cells/mL (Hamann et al., 2005). However, increased SCC may not necessarily be a sign of clinical mastitis (Table 1; Figure 1). In reality, true udder health status must be based on only the presence of microbial pathogens (Hamann et al., 2005). Intramammary infection upon microbiological culturing are associated with increased SCC and CMT score (McDermott et al., 1982; Sargeant et al., 2001).

The ROC curves are employed to determine the usefulness of direct and indirect measurements or tests for screening diseases. As seen in Table 2, at increased threshold levels, sensitivity increased and specificity decreased (McDermott et al., 1982; Werven et al., 2005). The sensitivity and specificity of CMT were 84.1 and $97.5 \%$, respectively, when mammary gland status was assessed by milk culture and 61.22 and $79.6 \%$, respectively, when mammary gland status was assessed by SCC (Gharagozloo et al., 2003). Wahba et al. (2005) reported that the sensitivity of Whiteside Test, CMT, 
and SCC was 86.1, 64.6, and $74.7 \%$, respectively, and their agreements with major pathogen isolation were 80,60 , and $72.9 \%$, respectively. Somatic cell count can be high despite lacking IMI or low despite presence of IMI. An SCC threshold of 100,000 cells/mL for quarter samples was reported to have the maximal sensitivity and specificity for detecting IMI (Sargeant et al., 2001); the sensitivities for detecting IMI with any pathogen, IMI with a major pathogen, and IMI with a minor pathogen were 56.7, 66.7, and 49.5, respectively. Djabri et al. (2002) reported that at an SCC threshold of 265,000 cells/mL the sensitivity and specificity were 71 and $76 \%$, respectively, when minor and major pathogens were considered, whereas at an SCC threshold of 420,000 cells/mL the sensitivity and specificity were 83 and $84 \%$, respectively, when only major pathogens were considered. In another experiment, the sensitivity and specificity to detect positive bacteriological culture were reported to be 74.4 and $58.1 \%$, respectively, for SCC (cut-off value of 250,000 cells/mL) and 46.3 and $81.9 \%$, respectively, for CMT (cut-off value of +2 ; Werven et al., 2005). In this experiment, microbiological culturing was not performed; instead, SCC was used to define subclinical mastitis and the reliability of IRT was compared with CMT to detect subclinical mastitis. Similar to our data (Table 1; Figures 1 and 2), the existence of high correlations among test results and measures is well documented (Brito et al., 1997; Gharagozloo et al., 2003; Wahba et al., 2005; Roesch et al., 2007; Colak et al., 2008). However, other than culture test, currently practiced indicators (SCC and $\mathrm{CMT}$ ) are subjective (Sen et al., 1996; Ferraro et al., 1999) and their cutoffs to differentiate healthy versus subclinical mastitic quarters vary by country and scientific document (De Vliegher et al., 2001; Redetzky et al., 2005; Chagunda et al., 2006).

Thermal conditions in tissues and organs are influenced by fluctuations in the amount and rate of blood supply, which permit the observation of activities within regions of interest (Purohit and McCoy, 1980; Hurnik et al., 1984; Schaefer et al., 2000). Function loss, redness, pain, swelling, and hyperthermia are major signs in the early stage of clinical inflammations (Cheville, 1999) and skin surface temperature reflects the underlying circulation and tissue metabolism (Berry et al., 2003). For example, Schaefer et al. (2007) was able to detect bovine respiratory disease 4 to $6 \mathrm{~d}$ before onset of clinical symptoms using IRT with 80,65 , and $71 \%$ of the positive and negative predictive values and test efficiency, respectively, compared with 70,45 , and $55 \%$, respectively, via clinical scoring in weaned calves. Hurnik et al. (1984) showed that IRT was able to detect 4 out of 6 mastitis cases and detection ability was superior in severe systemic infections. Moreover, monitoring

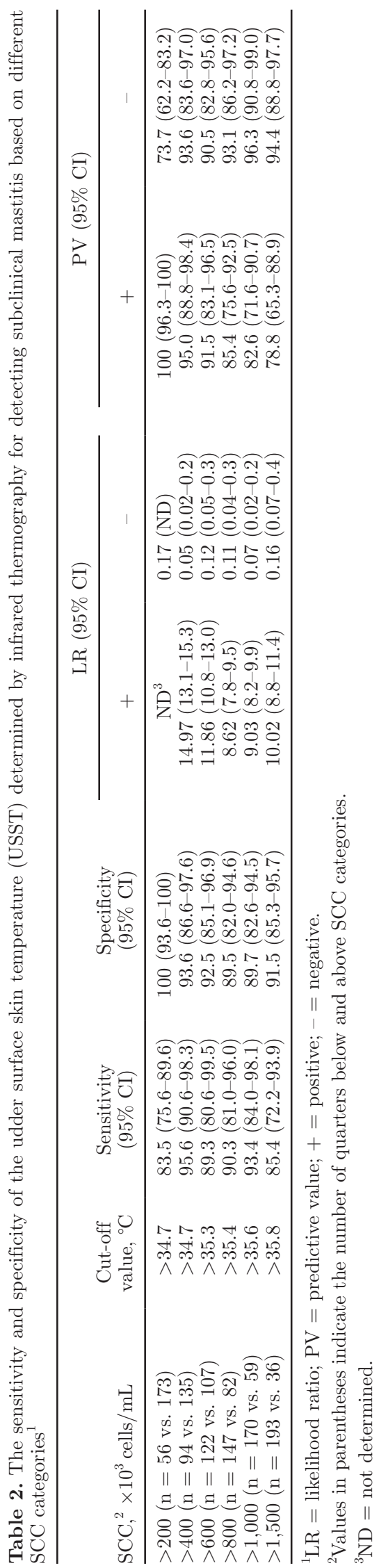

Journal of Dairy Science Vol. 93 No. 8, 2010 


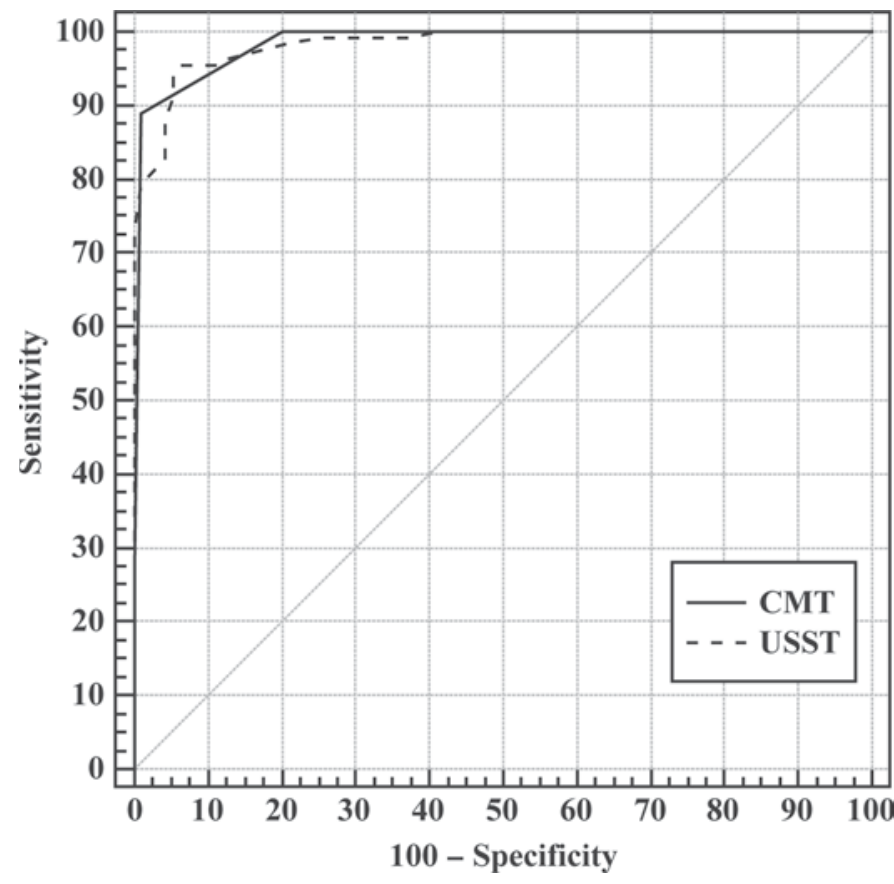

Figure 2. The sensitivity and specificity of the udder skin surface temperature (USST) determined by infrared thermography (IRT) and the California Mastitis Test (CMT) score when quarters were categorized as healthy $(\mathrm{SCC} \leq 400,000$ cells $/ \mathrm{mL}, \mathrm{n}=94)$ versus subclinical mastitic $(\mathrm{SCC}>400,000$ cells $/ \mathrm{mL}, \mathrm{n}=135)$. The sensitivity, specificity, positive likelihood ratio, negative likelihood ratio, positive predictive value, and negative predictive value were 95.6, 93.6, 14.97, 0.05 95.0, and 93.6, respectively, for IRT and 88.9, 98.9, 83.56, 0.11, 99.2, and 86.1, respectively, for CMT. The area under the receiver operating characteristics curve for IRT and CMT was 0.985 and 0.983 ( $z$-value $=0.19, P<0.85$ )

mastitis revealed that temperature started to increase 3 d before clinical signs (Hurnik et al., 1984). Scott et al. (2000) also demonstrated that endotoxin infusion into the udder to induce an inflammatory response similar to mastitis led a detectable temperature increase $\left(+2.3^{\circ} \mathrm{C}\right)$ in udder skin measured by IRT. Because early diagnosis is crucial for success of the mastitis treatment, determination of USST using IRT may have considerable diagnostic merit. To our knowledge, however, few IRT data are available to compare its reliability with other tests in early detection of subclinical mastitis in cows.

Although the physiological threshold of SCC $(100,000$ cells $/ \mathrm{mL}$ ) is determined (Redetzky et al., 2005), SCC threshold for defining subclinical mastitis is variable. Quarters with an SCC below and above 100,000 cells/ $\mathrm{mL}$ were reported to have USST of 33.6 and $34.1^{\circ} \mathrm{C}$, respectively (Barth, 2000). In contrast, Janeczek et al. (1999) in cows and Militaru et al. (2005) in dogs reported no differences in temperatures of healthy and infected or cancerous mammary glands. In humans, however, temperature increases $\left(+3^{\circ} \mathrm{C}\right)$ because of tumors (Potter et al., 1997) as well as exact definition of their topography and distribution for irradiation (Gabuniia et al., 1980) were achieved by IRT. In the present study (Table 2), subclinical mastitic quarters (SCC $>400,000$ cells $/ \mathrm{mL}$ ) had a $2.35^{\circ} \mathrm{C}$ greater skin surface temperature than healthy quarters (SCC $\leq 400,000$ cells/mL). In a recent study by Hovinen et al. (2008), it was shown that IRT was capable of detecting 1 to $1.5^{\circ} \mathrm{C}$ change on USST associated with clinical mastitis induced by lipopolysaccharide.

Despite proven ability to detect temperature increase by IRT (Barth, 2000; Hovinen et al., 2008), studies on its diagnostic reliability for clinical or subclinical mastitis in cows are lacking. Infrared thermography is also an indirect measure, but it has relatively greater sensitivity, specificity, and positive and negative predictive values (Table 2; Figure 2) than other subjective tests or measures reported in the literature (Jensen and Knudsen, 1991; Woolford et al., 1998; Bansal et al., 2005; Chagunda et al., 2006). Some reports dealing with the sensitivity and specificity of IRT in human breast diseases are available. Yokoe et al. (1990) reported that the sensitivity and specificity of IRT for testing breast cancer in women were 81.5 and $83.5 \%$, respectively.

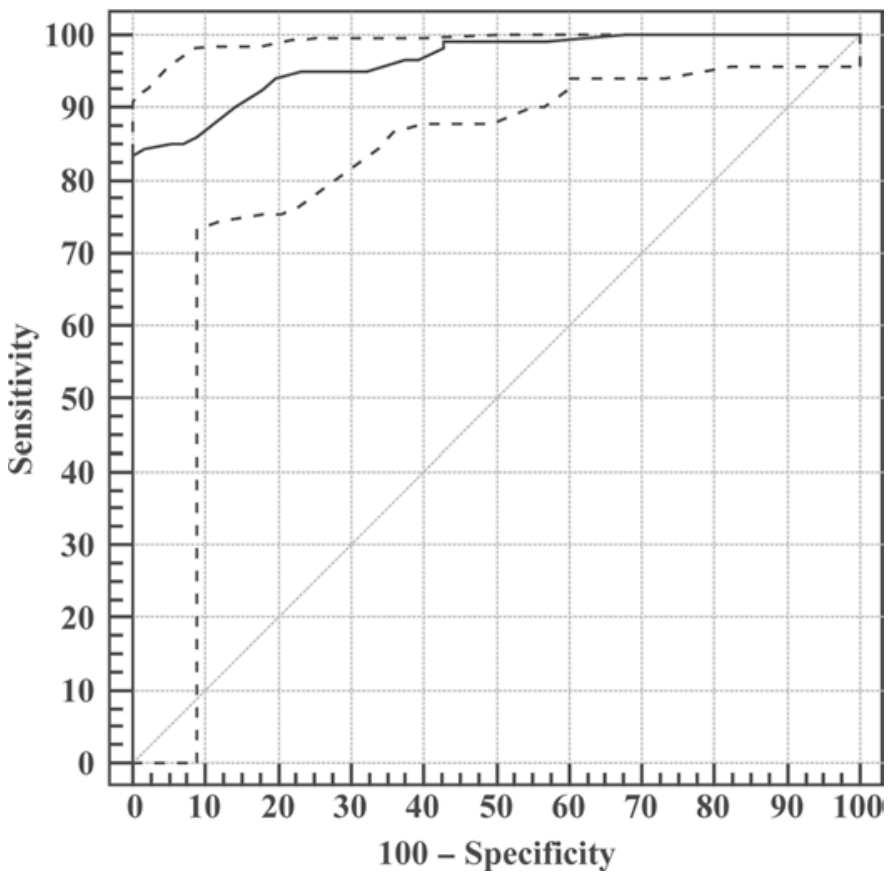

Figure 3. The sensitivity and specificity of the udder skin surface temperature determined by infrared thermography when quarters were categorized as healthy ( $\mathrm{SCC} \leq 200,000$ cells $/ \mathrm{mL}, \mathrm{n}=56$ ) versus subclinical mastitic (SCC >200,000 cells $/ \mathrm{mL}, \mathrm{n}=173$ ). Broken lines indicate $95 \%$ confidence interval. The sensitivity, specificity, positive likelihood ratio, negative likelihood ratio, positive predictive value, and negative predictive value were 83.47 (75.6-89.6), 100 (93.6-100), not determined, 0.17 (not determined), 100 (96.4-100), and 73.7 $(62.2-83.2)$, respectively, at cut-off of $34.7^{\circ} \mathrm{C}$. Values in parentheses are $95 \%$ confidence interval. 
The diagnostic sensitivity of IRT was reported to be $97.1 \%$ in 209 women with mastitis, with low specificity (Gurtovoi et al., 1990).

\section{CONCLUSIONS}

In conclusion, because of no microbiological culturing data, mammary gland status was based on SCC (at cut-off of 400,000 cells/mL). Subclinical mastitic quarters had a $2.35^{\circ} \mathrm{C}$ greater skin surface temperature than healthy quarters. The ROC curve revealed that sensitivity and specificity of IRT (95.6 and 93.6\%, respectively) were not different from those for CMT (88.9 and 98.9\%, respectively), a routinely used subjective measure in dairy operations. In addition to being a noninvasive and quick tool, IRT was sensitive enough to detect thermal changes on udder skin caused by subclinical mastitis. It may help veterinarians and herdsmen in early detection of subclinical mastitis, and consequently help execution of immediate and effective treatment. However, further studies should investigate the reliability of IRT among cows with different characteristics such as parity, milk production, time relative to feeding, and milking and cows under various environmental conditions such as air temperature, velocity, and humidity, which were not taken into account in this experiment. Further studies should also determine the sensitivity and specificity of IRT in subclinical mastitic quarters ascertained by microbiological evaluation.

\section{REFERENCES}

Bansal, B. K., J. Hamann, N. T. Grabowski, and K. B. Singh. 2005. Variation in the composition of selected milk fraction samples from healthy and mastitic quarters, and its significance for mastitis diagnosis. J. Dairy Res. 72:144-152.

Barth, K. 2000. Basic investigations to evaluate a highly sensitive infrared-thermograph technique to detect udder inflammation in cows. Milk Sci. Int. 55:607-609.

Berry, R. J., A. D. Kennedy, S. L. Scott, B. L. Kyle, and A. L. Schaefer. 2003. Daily variation in the udder surface temperature of dairy cows measured by infrared thermography: Potential for mastitis detection. Can. J. Anim. Sci. 83:687-693.

Bitman, J., A. Lefcourt, D. L. Wood, and B. Stroud. 1984. Circadian and ultradian temperature rhythms of lactating dairy cows. J. Dairy Sci. 67:1014-1023.

Brito, J. R. F., G. A. V. Caldeira, R. D. Verneque, and M. A. V. P. E. Brito. 1997. Sensitivity and specificity of the California Mastitis Test as a diagnostic tool for subclinical mastitis in quarter somatic cell count estimation. Pesqui. Vet. Bras. 17:49-53.

Chagunda, M. G., T. Larsen, M. Bjerring, and K. L. Ingvartsen. 2006. L-lactate dehydrogenase and N-acetyl-beta-D-glucosaminidase activities in bovine milk as indicators of non-specific mastitis. J. Dairy Res. 73:431-440.

Cheville, N. F. 1999. Inflammation and healing. Pages 101-102 in Introduction to Veterinary Pathology. 2nd ed. Iowa State University Press, Ames.

Clark, J. A., and K. Cena. 1977. The potential of infra-red thermography in veterinary diagnosis. Vet. Rec. 100:402-404.
Colak, A., B. Polat, Z. Okumus, M. Kaya, L. E. Yanmaz, and A. Hayirli. 2008. Short communication: Early detection of mastitis using infrared thermography in dairy cows. J. Dairy Sci. 91:42444248.

De Vliegher, S., H. Laevens, G. Opsomer, E. De Muelenaere, and A. De Kruif. 2001. Somatic cell counts in dairy heifers during early lactation. Flemish Vet. J. 70:212-215.

Djabri, B., N. Bareille, B. Poutrel, F. Beaudeau, M. Ducelliez, and H. Seegers. 2002. Accuracy of the detection of intramammary infection using quarter somatic cell count when taking parity and stage of lactation of the dairy cow into account. Anim. Res. 51:135-148.

Eddy, A. L., L. M. van Hoogmoed, and J. R. Snyder. 2001. Review: The role of thermography in the management of equine lameness. Vet. J. 162:172-181.

Erskine, R. J., S. Wagner, and F. J. DeGraves. 2003. Mastitis therapy and pharmacology. Vet. Clin. North Am. Food Anim. Pract. 19:109-138.

Ferraro, L., A. Scaramelli, and H. Troya. 1999. Prevalence of subclinical bovine mastitis in Venezuela and evaluation of California Mastitis Test (CMT). Rev. Cient. Fac. Cien. 9:81-90.

Gabuniia, R. I., O. P. Lenskaia, I. B. Bogdasarov, S. A. Bal'ter, and V. G. Sakharovskaia. 1980. Importance of thermography in the overall examination of oncological patients. Med. Tekh. 4:19-21. (In Russian.)

Gharagozloo, F., M. Blourchi, A. M. Tabatabaee, H. G. Nava, and M. Vojgani. 2003. Sensitivity and specificity of CMT to detect subclinical mastitis in dairy cows. Anim. Fishery Sci. 59:59-62. (In Persian.)

Gurtovoi, B. L., O. E. Ozerova, and B. U. Nauryzbaeva. 1990. Clinical value of telethermography in the diagnosis of puerperal mastitis. Akush. Ginekol. (Mosk.) 12:36-38. (In Russian.)

Hamann, J., R. Redetzky, and N. Th. Grabowski. 2005. Diagnostic potential of the California mastitis test to detect subclinical mastitis. Pages 15-21 in Mastitis Newsletter 26. H. Hogeveen, ed. International Dairy Federation, Brussels, Belgium.

Holanda, E. V. Jr., F. E. Madalena, E. D. Holanda, W. M. Miranda, and M. R. Souza. 2005. Economic impact of mastitis in six farms of Araxa-Minas Gerais state, Brazil. Arch. Latinoam. Prod. Anim. 13:63-69.

Hovinen, M., J. Siivonen, S. Taponen, L. Hänninen, M. Pastell, A. M. Aisla, and S. Pyörälä. 2008. Detection of clinical mastitis with the help of a thermal camera. J. Dairy Sci. 91:4592-4598.

Hurnik, J. F., S. DeBoer, and A. B. Webster. 1984. Detection of health disorders in dairy cattle utilizing a thermal infrared scanning technique. Can. J. Anim. Sci. 64:1071-1073.

Janeczek, W., B. Chudoba-Drozdowska, J. Twardon, and Z. Samborski. 1999. Critical notices about some thermal parameters for evaluation of the health of the mammary gland in dairy cows. Tierarztl. Prax. G.N. 27:258-262 (In German.)

Jensen, N. E., and K. Knudsen. 1991. Interquarter comparison of markers of subclinical mastitis: Somatic cell count, electrical conductivity, N-acetyl-beta-glucosaminidase and antitrypsin. J. Dairy Res. 58:389-399.

Kennedy, A. D., R. J. Berry, S. L. Scott, B. L. Kyle, and A. L. Schaefer. 2003. Daily variation in the udder surface temperature of dairy cows measured by infrared thermography: Potential for mastitis detection. Can. J. Anim. Sci. 83:687-693.

Knížková, I., P. Kunc, G. A. K. Gürdil, Y. Pınar, and K. Ç. Selvi. 2007. Applications of infrared thermography in animal production. J. Fac. Agric. OMU 22:329-336.

Kunc, R., I. Knížková, M. Přikryl, and J. Maloun. 2007. Infrared thermography as a tool to study the milking process: A review. Agricultura Tropica et Subtropica 40:29-32.

Mazur, D., and J. W. Eugeniusz-Herbut. 2006. Infrared thermography as a diagnostic method. Roczniki Naukowe Zootechniki 33:171181. (In Polish.)

McDermott, M. P., H. N. Erb, and R. P. Natzke. 1982. Predictability by somatic cell counts related to prevalence of intramammary infection within herds. J. Dairy Sci. 65:1535-1539. 
McDougall, S. 1999. Prevalence of clinical mastitis in 38 Waikato dairy herds in early lactation. N. Z. Vet. J. 47:143-149.

Menesatti, P., M. Iacurto, S. D'Andrea, M. Pincu, and F. Saltalamacchia. 2004. Infrared thermography for monitoring animal welfare. Informatore Agrario 60:49-53.

Militaru, M., E. Ciobotaru, J. Mocanu, T. Soare, G. Dinescu, and C. Serbanoiu. 2005. Comparative study between histological aspects and values of thermography in bitch mammary tumoral disease. J.U. Agric. Sci. Vet. Med. Cluj-Napoca 62:191-194 (In Romanian.)

Potter, H., R. Horne, K. Le May, and J. Seah. 1997. The sensitivity of thermography to temperature changes in breast tissue. Aust. J. Physiother. 43:205-210.

Purohit, R. C., and M. D. McCoy. 1980. Thermography in the diagnosis of inflammatory processes in the horse. Am. J. Vet. Res. 41:1167-1174

Rajala-Schultz, P. J., and Y. T. Grohn. 1999. Culling of dairy cows. Part I. Effects of diseases on culling in Finnish Ayrshire cows. Prev. Vet. Med. 41:195-208.

Redetzky, R. J. Hamann, N. T. Grabowski, and G. Klein. 2005. Diagnostic value of the California Mastitis Test in comparison to electronically-counted somatic cells in bovine milk. Pages 487-494 in Mastitis in Dairy Production. Proc. 4th IDF International Mastitis Conference, Maastricht, the Netherlands. H. Hogeveen, ed. Wageningen Acad. Press, Wageningen, the Netherlands.

Roesch, M., M. G. Doherr, W. Scharen, M. Schallibaum, and J. W. Blum. 2007. Subclinical mastitis in dairy cows in Swiss organic and conventional production systems. J. Dairy Res. 74:86-92

Sargeant, J. M., K. E. Leslie, J. E. Shirley, B. J. Pulkrabek, and G. H. Lim. 2001. Sensitivity and specificity of somatic cell count and California Mastitis Test for identifying intramammary infection in early lactation. J. Dairy Sci. 84:2018-2024.

Sargeant, J. M., H. M. Scott, K. E. Leslie, M. J. Ireland, and A. Bashiri. 1998. Clinical mastitis in dairy cattle in Ontario: Frequency of occurrence and bacteriological isolates. Can. Vet. J. 39:33-38

SAS. 1999. User's Guide: Statistics. Version 8. SAS Inst. Inc., Cary, NC.

Schaefer, A. L., N. J. Cook, J. S. Church, J. Basarab, B. Perry, C Miller, and A. K. W. Tong. 2007. The use of infrared thermography as an early indicator of bovine respiratory disease complex in calves. Res. Vet. Sci. 83:376-384.

Schaefer, A. L., S. V. Tessaro, D. Deregt, G. Desroches, N. G. Cook, P. Lepage, J. J. Colyn, P. L. Dubeski, and D. L. Godson. 2000. Early detection of infection using infrared thermography. Can. J. Anim. Sci. 80:772. (Abstr.)

Schaefer, A. L., N. Cook, S. V. Tessaro, D. Deregt, G. Desroches, P. L. Dubeski, A. K. W. Tong, and D. L. Godson. 2004. Early detection and prediction of infection using infrared thermography. Can. J Anim. Sci. 84:73-80.

Schalm, O. W., and D. O. Noorlender. 1957. Experiments and observations leading to development of the California mastitis test. J. Am. Vet. Med. Assoc. 130:199-204.

Scott, S. L., A. L. Schaefer, A. K. W. Tong, and P. Lacasse. 2000. Use of infrared thermography for early detection of mastitis in dairy cows. Can. J. Anim. Sci. 80:764. (Abstr.)

Sears, P. M., and K. K. McCarthy. 2003. Diagnosis of mastitis for therapy decisions. Vet. Clin. North Am. Food Anim. Pract. 19:93-108.

Sen, M. M., M. H. Kabir, and A. Rahman. 1996. Application of indirect tests to detect the sub-clinical mastitis in milk cows. Bangladesh Vet. J. 30:137-139.

Stewart, M., J. R. Webster, A. L. Schaefer, N. J. Cook, and S. L. Scott. 2005. Infrared thermography as a non-invasive tool to study animal welfare. Anim. Welf. 14:319-325.

Stewart, M., J. R. Webster, G. A. Verkerk, A. L. Schaefer, J. J. Colyn, and K. J. Stafford. 2007. Non-invasive measurement of stress in dairy cows using infrared thermography. Physiol. Behav. 92:520525.

Viguier, C., S. Arora, N. Gilmartin, K. Welbeck, and R. O'Kennedy 2009. Mastitis detection: Current trends and future perspectives. Trends Biotechnol. 27:486-493.

Wahba, N. M., M. M. Ali, and M. M. A. El-Hafeez. 2005. Microbiologica profile of subclinical mastitic cow milk and its correlation with field tests and the somatic cell count. Assiut Vet. Med. J. 51:62-75.

Werven, T. V., C. Nijhof, T. V. Bussel, and H. Hogeveen. 2005. Use of on-farm testing of somatic cell count for selection of udder quarters for bacteriological culturing. Pages 481-486 in Mastitis in Dairy Production: Current Knowledge and Future Solutions. Proc. 4th IDF International Mastitis Conference, Maastricht, the Netherlands. H. Hogeveen, ed. Wageningen Acad. Press, Wageningen, the Netherlands.

Willard, S., S. Dray, R. Farrar, M. McGee, S. Bowers, A. Chromiak, and M. Jones. 2007. Use of infrared thermal imaging to quantify dynamic changes in body temperature following lipopolysaccharide (LPS) administration in dairy cattle. J. Anim. Sci. 85(Suppl. 2):26

Woolford, M. W., J. H. Williamson, and H. V. Henderson. 1998 Changes in electrical conductivity and somatic cell count between milk fractions from quarters subclinically infected with particular mastitis pathogens. J. Dairy Res. 65:187-198.

Yokoe, T., T. Ishida, T. Ogawa, Y. Iino, T. Kawai, and M. Izuo. 1990. Role of cancer thermography for detection of breast cancer. Gan No Rinsho 36:885-889. (In Japanese.) 